\title{
Patent Norm Conflict on Trade-Related Aspect Intellectual Property Rights (TRIPs) in Mining Perspective
}

\author{
Anak Agung Sagung Ngurah Indradewi \\ Law Faculty \\ Dwijendra University \\ Bali, Indonesia \\ rbp.prabu@gmail.com
}

\begin{abstract}
Law No. 4 of 2009 on Minerals and Coal constitutes the legal basis of mining business activities in Indonesia, in which case foreign companies shall be subject to the provisions of Law Number 13 Year 2016 regarding Patents in the context of holders of mining patents. The provisions of Article 20 paragraph (1) of Law Number 13 Year 2016 regarding Patent states that the Patent holder is obliged to make products or use the process in Indonesia. In the perspective of mining products the process is mandatory in Indonesia, the provision is aimed at patent holders not only to import mining products but they should be able to invest by making mining companies in Indonesia, so that ultimately can occur the absorption of Indonesian workforce in the field of mining business. This is in line with the provisions of Article 20 paragraph (2) stating making the product or using the process referred to in paragraph (1) shall support the transfer of technology, the absorption of investment and / or the provision of employment. However, such provision if traced is contrary to the principle of non-discrimination set forth in the terms of the Trade-Related As pect Intellectual Property Rights (TRIPs) that Indonesia has ratified as Law no. 7 of 1994 on Ratification of Agreement Establishing The World Trade Organization, Article 27 paragraph (1) of the TRIPS Agreement states that a Patent shall be available and patents are enjoyed without discrimination in respect of where it is found, in technology and whether the product is imported or produced locally, The conventional conflict in the perspective of a mining company lies with the subject of patent holders and / or foreign mining companies holding patents in Indonesia shall establish a mining factory in Indonesia that produces a patent product registered in its name in Indonesia, if a mining plant is not present in Indonesia the mining patent is not recognized in Indonesia.
\end{abstract}

Keywords- norm conflict, patent rights, Trade-Related Aspect Intellectual Property Rights (TRIPs), mining

\section{INTRODUCTION}

The mineral and coal mining contained in the Indonesian mining legal territory is a non-renewable natural resource as a gift of God Almighty who has an important role in fulfilling the livelihood of the people, therefore the management must be controlled by the State to provide real added value to the national economy in efforts to achieve prosperity and prosperity of the people in justice.

Mineral and coal mining business activities which are business activities that have an important role in providing significant added value to national economic growth and sustainable regional development.

Law No. 4 of 2009 on Minerals and Coal constitutes the legal basis of mining business activities in Indonesia, in which case foreign companies shall be subject to the provisions of Law Number 13 Year 2016 regarding Patents in the context of holders of mining patents. The provisions of Article 20 paragraph (1) of Law Number 13 Year 2016 regarding Patent states that the Patent holder is obliged to make products or use the process in Indonesia.

In the perspective of mining products the process is mandatory in Indonesia, the provision is aimed at patent holders not only to import mines but they should be able to invest related to mining in Indonesia, so that ultimately can occur the absorption of Indonesian workforce in the field of mining business. This is in line with the provisions of Article 20 paragraph (2) of Law Number 13 Year 2016 regarding Patents stating making products or using the process referred to in paragraph (1) should support technology transfer, investment absorption and / or employment provision.

The Indonesian State has ratified the Trade-Related Aspect Intellectual Property Rights (TRIPs) which has been ratified into Law no. 7 of 1994 on Ratification of Agreement Establishing The World Trade Organization. Law Number 7 of 1994 as the legal basis for Ratification of Agreement on Establishing the World Trade Organization (WTO). This ratification brings consequences for Indonesia to comply fully with the WTO agenda including Agreement on Trade Related Aspects of Intellectual Property Rights Including Trade in Counterfeit Goods. To that end, Indonesia must improve or make laws and regulations in the field of intellectual property rights (IPR) as well as on patent arrangements in Indonesia.

Intellectual property rights are the official translation of Intellectual Property Rights. HKI was born after the Industrial Revolution, starting from the Paris Convention for the Protection of Industrial Property and Berne Conventon for the Protection of Artistic and Literaty works in the 19th century.

Intellectual property rights are intellectual property rights in this case began to be fought as individual rights in countries that have a Common Law or Anglo Saxon legal system in which property rights are actually championed as 
individual rights. The Common Law and Continental European legal system has a different understanding of property rights. In the Common Law legal system this can be seen in its Private Law where detailed legal property rules are in place, while the Continental European legal system is not.

Intellectual property rights are closely related to objects (intangible) and protect intellectual works born from human creations, tastes and intentions. WIPO (World Intellectual Property Organization), an international agency under the United Nations (UN) that deals with IPR issues, defines IPR as; "Creations resulting from the human mind that include; invention, literary and artistic works, symbols, names, images and designs used in commerce.

The birth of Law No. 13 of 2016 on Patents is part of the protection of intellectual property rights, that patents are intellectual property provided by the state to the inventors of their invention in the field of technology that has a strategic role in supporting the development of the nation and promoting the common prosperity, one of them technology in mining that is in line with mining business activities under Law No. 4 of 2009 on Minerals and Coal.

In the provisions of Law Number 13 Year 2016 on Patents, Article 1 Paragraph (1) states that a Patent is an exclusive right granted by the State to the inventor of his invention in the field of technology for a certain period of time of carrying out the invention himself or giving approval to another party to implement it. Article 1 Paragraph (2) states that an Invention is an inventory idea poured into a specific problem-solving activity in the field of technology in the form of a product or process, or improvement and development of a product or process, and in Article 1 paragraph (3) stating the Inventor is a some people who jointly implement the ideas poured into the activities that resulted in the Invention.

Judging from the provisions of the above opening articles in the provisions of Law Nu mber 13 Year 2016 on Patents, It is clear that patent protection and definition of patent law subject. However, in the provision of Article 20 paragraph (1) of Law Number 13 Year 2016 regarding Patent, the patent holder is obliged to make a product or use process in Indonesia. Article 20 Paragraph (1) of Law Number 13 of 2016 concerning the Patent if traced is contrary to the principle of non-discrimination set forth in the provisions of Article 27 paragraph (1) of the TRIPS Agreement states, "Patents must be available and patents are enjoyed without discrimination with where it is found, in technology and whether the product is imported or produced locally.

Trade-Related Aspect Intellectual Property Rights (TRIPs) which have been ratified by the state of Indonesia into Law no. 7 of 1994 on Ratification of Agreement Establishing The World Trade Organization, the general outline of the conflict of norms between Law No. 13 of 2016 on Patents with Law no. 7 of 1994 on Ratification of Agreement Establishing The World Trade Organization. In relation to the above, it is necessary for the authors to review and examine the "Patent Rights in Trade-Related Aspect Intellectual Property Rights (TRIPs)".

\section{PROBlem Formulation AND METHOD}

How does Patent norms conflict in the Trade-Related Aspect Intellectual Property Rights (TRIPs) in a mining perspective?.

In order for a paper based on research can be said to meet the criteria as a scientific work, then needed a method. In relation to this matter, in the preparation of this paper, the author uses normative juridical method of research legislation and literature analysis and other legal materials such as books and legal journals.

\section{CONFLICT OF NORMS OF PATENT ON TRADE-RELATED ASPECT INTELLECTUAL PROPERTY RIGHTS (TRIPS) IN MINING PERSPECTIVE}

Law No. 4 of 2009 on Minerals and Coal, in article 1 point 1 states that Mining is part or all of the phases of activities in the framework of research, management and exploitation of minerals or coal covering general investigation, exploration, feasibility study, construction, mining, processing and refining, transporting and selling, as well as activities, pascatambang.

Law No. 4 of 2009 on Minerals and Coal constitutes the legal basis of mining business activities in Indonesia, in which case foreign companies shall be subject to the provisions of Law Number 13 Year 2016 regarding Patents in the context of holders of mining patents.

Patent norm conflicts In the Trade-Related Aspect Intellectual Property Rights (TRIPs) in the mining perspective are listed in the provisions of Article 20 paragraph (1) of Law Number 13 Year 2016 regarding Patents with the provisions of Article 27 paragraph (1) TRIPS Agreement (Undang- Act No. 7 of 1994 on Ratification of Agreement Establishing The World Trade Organization).

Article 20 paragraph (1) of Law Number 13 Year 2016 regarding Patent states that Patent holder is obliged to make products or use process in Indonesia. This requires the patent holder to make a mining product or use the process of a mining plant in Indonesia, in international practice it can cause problems, this is because it is in conflict with TradeRelated Aspect Intellectual Property Rights (TRIPs).

TRIPS Agreement is an international agreement relating to aspects of intellectual property rights. This agreement has been ratified by the Indonesian government through Law Number 7 of 1994. Actually, the law is entitled the Ratification of Agreement Establishing the World Trade Organization (TRAN) where TRIPS Agreement is in it.

The principle of non-discrimination set forth in the provisions of Article 27 paragraph (1) of the TRIPS Agreement states, "Patents shall be available and patents are enjoyed without discrimination in respect of where they are found, in technology and whether they are imported or produced locally." the perspective of mining business activities may be conducted overseas or in countries of the world, without forcing any State to open a factory or mining company in the country to be imported.

Article 20 paragraph (1) of Law Number 13 Year 2016 regarding Patent states that Patent holder is obliged to make products or use process in Indonesia. That such duty is contrary to the principle of non-discrimination as set forth in 
the international agreement, Agreement on Trade-Related Aspects of Intellectual Property Rights (TRIPS). In the perspective of mining business activities, the subjects of the patent holders of mining and or foreign companies mining patent holders in Indonesia shall establish a factory or a mining company in the State of Indonesia producing the patent product registered in its name in Indonesia, if its factory or mining company in Indonesia does not exist then the patent mining is not recognized in Indonesia.

In the identification of the rule of law is often found the state of the rule of law, namely legal vacuum (leemten in het recht), conflicts between legal norms (legal antinomy), and vague norms or unclear norms. In the face of conflict between legal norms (legal antinomy), then apply the principles of conflict resolution (principle of preference), namely:

1. Lex superiori derogat legi inferiori, ie higher legislation will paralyze the lower legislation;

2. Lex specialis derogat legi generali, a special rule that would disable the general rules or special rules that must take precedence;

3. Lex posteriori derogat legi priori, the new rules beat or paralyze the old rules.

In the context of the conflict of norms between Law Number 13 Year 2016 on Patents with Law no. 7 of 1994 on Legalization of WTO / TRIPS is based on the Lex posteriori derogat legi priori principle, that is, the new rules defeat or paralyze the old regulations, meaning that Law Number 13 Year 2016 on Patents which is a new law automatically defeats or paralyzes the rules the old one is Law no. 7 of 1994 on Legalization of WTO / TRIPS.

In particular, based on the principle of Lex specialis derogat legi generali, a special rule that would disable the general rules or special rules that should take precedence, then Law No. 13 of 2016 on Patents which is a special law on patents automatically defeats or paralyzing the general rule of law. 7 of 1994 on Legalization of WTO / TRIPS.

International objections in this case The United States Chamber of Commerce or the United States Chamber of Commerce in Indonesia, assess the obligation raises a number of significant concerns for companies of foreign origin patent holders in Indonesia. Moreover, in practice, not a few mining companies register patents in many countries. According to The United States Chamber of Commerce in Indonesia, it is not practical to set up a mining company plant in all countries and most mining companies rely on sophisticated supply and distribution chains to serve their customers worldwide.

According to the opinion of the author in this study, it is reasonable that the Indonesian government endorsed Article 20 Paragraph (1) of Law Number 13 Year 2016 regarding Patent states that the Patent Holder is obliged to make products or use the process in Indonesia. The provision is intended for patent holders not only to import but they should be able to invest in Indonesia by making mining companies in Indonesia, so that ultimately can occur the absorption of Indonesian workers. This is in line with the provisions of Article 20 paragraph (2) of Law Number 13 Year 2016 regarding a Patent stating making the product or using the process referred to in paragraph (1) should support technology transfer, investment absorption and / or employ ment provision, with Law No. 4 of 2009 on Minerals and Coal is the legal basis for mining business activities in Indonesia.

In this case the State of Indonesia can realize the workforce absorbed in the field of mining business, the government of Indonesia is invested with natural resources of minerals and coal and oil and gas scattered throughout Indonesia can be utilized, get taxes and product quality even patent rights in the field of mining owned by foreign citizens and / or foreign companies which of course welfare the people of Indonesia.

\section{CONCLUSIONS AND SUGGESTIONS}

Law No. 4 of 2009 on Minerals and Coal constitutes the legal basis of mining business activities in Indonesia, in which case foreign companies shall be subject to the provisions of Law Number 13 Year 2016 regarding Patents in the context of holders of mining patents. The provisions of Article 20 paragraph (1) of Law Number 13 Year 2016 regarding Patent states that the Patent holder is obliged to make products or use the process in Indonesia. However, the provision of Article 20 paragraph (1) of Law Number 13 Year 2016 regarding Patent is contradictory to the principle of non-discrimination which is stated in the Trade-Related Aspect Intellectual Property Rights (TRIPs) which has been ratified by the state of Indonesia as Law no. 7 of 1994 on Ratification of Agreement Establishing The World Trade Organization, Article 27 paragraph (1) of the TRIPS Agreement states, "Patents should be available and patents are enjoyed without discrimination in respect of where they are found, in technology and whether they are imported or produced locally. "In the perspective of its mining conflict business activities lies in the subject of the patent holder and / or foreign mining company the patent holder in Indonesia shall establish a factory in the State of Indonesia producing the mining patent product registered in his name in Indonesia, if his factory does not exist in Indonesia then the patent is not recognized in Indonesia.

In the context of the conflict of norms between Law Number 13 Year 2016 on Patents with Law no. 7 of 1994 on Legalization of WTO / TRIPS is based on the Lex posteriori derogat legi priori principle, that is, the new rules defeat or paralyze the old regulations, meaning that Law Number 13 Year 2016 on Patents which is a new law automatically defeats or paralyzes the rules the old one is Law no. 7 of 1994 on Legalization of WTO / TRIPS. In particular, based on the principle of Lex specialis derogat legi generali, a special rule that would disable the general rules or special rules that should take precedence, then Law No. 13 of 2016 on Patents which is a special law on patents automatically defeats or paralyzing the general rule of law. 7 of 1994 on Legalization of WTO / TRIPS.

The need for synergies of cooperation between interested international parties on Indonesian mining patents with the Indonesian Mining Services Association (ASPINDO), the Association of Intellectual Property Rights Consultants (AKHKI) and the Ministry of Law and Human Rights as the Indonesian government to provide input to the implementing regulations of the Law on Mining Rights Of Law No. 13 of 2016 on Patents for the achievement of justice, benefit and legal certainty in the context of mining patents. 


\section{REFERENCE}

[1] Ahmad Rifai, 2011, Legal Discovery by Judge in Progressive Law Perspective, Second Matter, Sinar Grafika, Jakarta.

[2] Achmad Zen Umar Purba, 2005, Intellectual Property Post TRIPs, Alumni, Bandung.

[3] Abdoel Djamali, 2006, Introduction to Indonesian Law, Raja Grafindo Persada, Jakarta.

[4] Sudikno Mertokusumo, 2002, Know the Law (An Introduction), Matter Third, Liberty, Yogyakarta.

[5] Tomy Suryo Utomo, 2010, Intellectual Property Rights (IPR) in the Global Era, Graha Ilmu, Yogyakarta. 